\title{
Quantitative assay of Indole Acetic Acid-producing bacteria isolated from several lakes in East Java, Indonesia
}

\author{
SULISTYA IKA RAMADHANI ${ }^{1}$, SITORESMI PRABANINGTYAS ${ }^{1, \bullet,}$ AGUNG WITJORO ${ }^{1}$, \\ RINA TRITURANI SAPTAWATI ${ }^{1}$, ACHMAD RODIANSYAH ${ }^{1}$ \\ Department of Biology, Faculty of Mathematics and Natural Sciences, Universitas Negeri Malang. Jl. Cakrawala No. 5, Kota Malang 65145, East Java, \\ Indonesia. Tel.: +62-341-562180, `email: sitoresmi.prabaningtyas.fmipa@um.ac.id
}

Manuscript received: 8 September 2020. Revision accepted: 27 October 2020

\begin{abstract}
Ramadhani SI, Prabaningtyas S, Witjoro A, Saptawati TR, Rodiansyah A. 2020. Quantitative assay of Indole Acetic Acidproducing bacteria isolated from several lakes in East Java, Indonesia. Biodiversitas 21: 5448-5454. Biofuel is an alternative to fossil fuels that are environmentally friendly with low emissions. Biofuel from biomass microalgae, especially Chlorella vulgaris, has an essential role in biofuel production. Increasing biomass microalgae was done by co-culture between microalgae and bacteria. This research aims to determine the potential of bacterial isolates to produce the IAA hormone and identify the highest isolate with the ability to synthesis IAA from four lakes in East Java. This research was conducted by culturing bacterial isolates in the Tryptic Soy Broth (TSB) to add tryptophan media in various periods of incubation. The absorbance was measured with UV-Vis spectrophotometry at a wavelength of $530 \mathrm{~nm}$ for determining IAA-production from bacterial isolates. The results showed that the "12" code bacterial isolate from Ranu Grati produced the highest IAA hormone concentration, with an average of $30.23 \mathrm{ppm}$. The morphological characterization of the highest IAA-producing bacteria showed that isolate included the Enterobacteriaceae group and phenotypic characterization include Enterobacter cloacae complex (ECC).
\end{abstract}

Keywords: Biofuels, East Java, IAA-producing bacteria, Lakes

\section{INTRODUCTION}

Fossil fuels are an essential source of energy today. In 2017-2025 the supply of power in Indonesia does not meet domestic needs, and the global demand for fuel expected to increase by $40 \%$ in 2025. Excessive use causes $\mathrm{CO}_{2}$ emissions and global warming (Sa'adah et al. 2017). Biofuel is an alternative source with low emissions from biological sources compared to fossil fuels (Tandon et al. 2017). Biofuel from plant cell walls represents an enormous biomass resource for the generation of biofuels and chemicals. Plant lignocelluloses, as the most abundant organic raw materials, are regarded as the best feedstock for ethanol biofuel production (Carroll and Somerville, 2009). Biofuel from microalgae especially Chlorellavulgaris has an essential role in producing biofuels in large quantities (Li et al. 2008; Jegathese dan Farid 2014). Increasing the growth of microalgae can be done by $\mathrm{co}^{-}$ culture between microalgae and bacteria. IAA-producing bacteria can provide exogenous auxins that had needed for the process of metabolizing microalgae to grow and produce biomass (Jusoh et al. 2015), because microalgae have a high oil and fat and not food ingredients because they are needed in large quantities (Kawaroe 2015). Biofuels can be obtained from various high-level plants or can be sourced from microalgae (Amini and Susilowati 2010). However, currently, microalgae are very good as raw material for biofuels because they can grow 15-300 times faster in producing biomass than other plants (Widodo et al. 2018)
Research with Scenedesmus sp. shows that the addition of IAA was able to increase biomass 1.9 times while other studies related to Chlorella pyrenoidosa increase biomass 2.2 times (Sivaramakrishnan dan Incharoensakdi 2020). The growth of Nannochloropsis oceanic was double moderately after adding IAA with a concentration of 10 ppm (Udayan et al. 2018). The interaction between microalgae and bacteria is a symbiosis of mutualisms, which shown the molecular exchange between single cells of microalgae and bacteria. This exchange gives benefits for microorganisms and can increase both (de-Bashan et al. 2016). The interaction between Chlorella sorokiniana and Azospirillum brasilense shows a combined effect with a marked increase in biomass growth and significant changes in the physiological, morphological, and biochemical pathways of microalgae. The interaction between IAAproducing bacteria and microalgae can stimulate the biomass of microalgae, especially in $C$. vulgaris. IAA plays an essential role in cell growth and metabolic processes. Besides, there is an exchange of metabolites between cells such as thiamine, tryptophan, IAA phytohormone, carbon, and nitrogen between single cells (Palacios et al. 2019).

This research explores the IAA-producing bacteria from Ranu Grati Ranu Pani, Ranu Regulo and Lake Ngebel located in East Java, Indonesia.

Those lakes have abundant diversity of microorganisms and could increase the utilization of biological resources in those areas (Lestariani 2014; Sharfina 2013). The aquatic ecosystem can present a lot of potencies, especially for sources of IAA-producing bacteria. This study aims to 
determine the ability of the bacterial isolate to produce IAA hormone and identify the highest IAA-producing bacteria. This bacteria will be carried out in future research to improve the growth of $C$. vulgaris in co-culture.

\section{MATERIALS AND METHODS}

\section{Isolates and cultures}

In the previous study, we had found 36 bacterial isolates from Ranu Grati, 24 bacterial isolates from Ranu Regulo, 14 bacterial isolates from Ranu Pani, and 36 bacterial isolates from Lake Ngebel that they were able to produce IAA hormone isolated from water samples (Prabaningtyas et al. 2017). The water salinity of the four lakes was around $0.00-0.4 \%, \mathrm{pH}$ was about 6.83-9.40, dissolved oxygen (DO) was between 4.2 and $11.6 \mathrm{mg} / \mathrm{L}$, and the water transparency was between 50 to $130 \mathrm{~cm}$ (Detail information of each lake can be seen in Supplementary materials 1). The isolate from Ranu Grati labeled with a "number", from Ranu Pani and Ranu Regulo labeled with the "alphabet", the isolate from Lake Ngebel was marked with the "alphabet" combined with "N". Those IAA-producing bacteria from the prior study were grown on Tryptic Soy Agar (TSA) media and incubated for 1 x 24 h. Bacterial isolates from pre-culture were re-cultured on TSB with addition tryptophan (50:1) volume and incubated with a rotary shaker with a speed of $120 \mathrm{rpm}$ for $4 \mathrm{x} 24 \mathrm{~h}$. Those new cultures were used for quantitative IAA measurement.

\section{Measurement of IAA hormone concentration}

Bacterial isolates were inoculated into $25 \mathrm{~mL}$ of TSB media that has been added to $0.5 \mathrm{~mL}$ tryptophan. The culture was incubated in a shaking incubator at $120 \mathrm{rpm}$. The sampling data was taken at $0,24,48,72 \mathrm{~h}$, which is the incubation time to determine specific time for highest IAAproduction. The $1.5 \mathrm{~mL}$ of culture was moved into a microtube, next centrifuged at $10.000 \mathrm{rpm}$ for $10 \mathrm{~min}$ (Shaik et al. 2016). A total of $1 \mathrm{~mL}$ of the supernatant was moved into a test tube after that $2 \mathrm{~mL}$ of Salkowski reagent (150 $\mathrm{mL} \mathrm{H}_{2} \mathrm{SO}_{4}$ concentrated and $7.5 \mathrm{~mL} \mathrm{FeCl}_{3} .6 \mathrm{H}_{2} \mathrm{O} 0.5$ M) was added (Gordon and Weber 1951). This solution incubated for $30 \mathrm{~min}$ in the dark at room temperature. For the next, IAA levels were measured using Libra S12 UVVis spectrophotometer (Biochorm, UK) with wavelength at $530 \mathrm{~nm}$ (Lwin et al. 2012), replicating in two times.

\section{Determination Optical Density (OD) of IAA-producing bacterial isolates}

OD of bacteria was measured by sampling $1.5 \mathrm{~mL}$ of TSB media that contain bacteria isolates based on absorbance value at a wavelength of $436 \mathrm{~nm}$ (Nghia et al. 2017). Sampling data were taken at incubation times 0, 24 , 48, and $72 \mathrm{~h}$ (Aryantha et al. 2004). The various incubation times were used to determine the growth phase of bacteria. This OD data was performed to show the correlation between the growth phases with the production of IAA by each isolate.

\section{Morphological characterization}

The highest IAA-producing bacteria were characterized by the colony and cell morphology. Observation of colony morphology contains color, shape, elevation, size, edges, and colony density. Observation of cell morphology includes gram staining, capsules staining, spores staining, the shape of bacteria cells, size of bacteria cells, cell movement, and type of respiration (Cappuccino and Sherman 2004).

\section{Genotypic characterization}

The bacterial isolate code "12" produced the highest IAA hormone was cultured in Nutrient Broth (NB) for $1 \times 24 \mathrm{~h}$ at $37^{\circ} \mathrm{C}$. A $10 \mathrm{~mL}$ suspension was taken from the culture and then centrifuged, and the pellets were used for gDNA isolation. Samples were isolated using the QIAmp DNA Mini Kit (Qiagen, Germany) following the manufacturer's protocol for bacterial isolation. The purity of gDNA after isolation will be measured using a NanoDrop ND-2000 Spectrophotometer (ThermoScientific, USA).

Top Taq Master Mix Kit Reagent is used for PCR reaction. PCR reaction profile as follows: initial denaturation $94^{\circ} \mathrm{C} / 3 \mathrm{~min}$, denaturation $94^{\circ} \mathrm{C} / 1 \mathrm{~min}$, annealing $50^{\circ} \mathrm{C} / 30 \mathrm{~s}$, extension $72^{\circ} \mathrm{C} / 1 \min 30 \mathrm{~s}$, final extension $72^{\circ} \mathrm{C} / 10 \mathrm{~min}$, and hold $4^{\circ} \mathrm{C}$. PCR products were examined on $1 \%$ gel electrophoresis, stained with Ethidium bromide (EtBr). The $100 \mathrm{bp}$ marker DNA was added to the gel to verify the amplicon band. The gel will be run on a MupidX® one electrophoresis apparatus; then, the suspicious band is visualized using a UV transilluminator.

PCR products are used for DNA sequencing at $1^{\text {st }}$ BASE Laboratories, Malaysia. Quality and order will be checked using FinchTV (available at https://digitalworldbiology.com/FinchTV). DNA Baser software is available at https://www.dnabaser.com/ to get the paired base sequences. Contig sequences were compared with nucleotides in NCBI (https://blast.ncbi.nlm.nih.gov) to ensure that the acquired genes were the target genes. Phylogenetic trees and genetic distances were calculated using the MegaX software (https://www.megasoftware.net/) with the NeighborJoining method (Pardi et al. 2016; Saitou and Nei 1987), including the 1000-replication bootstrap test.

\section{Data analysis}

The number of IAA from various incubation was analyzed with statistical descriptive; then it was visualized with the graph from the ten highest IAA-producing bacterial isolates.

\section{RESULT AND DISCUSSION}

\section{IAA standard curve}

The standard curve aims to obtain an equation for calculating the IAA concentration that have been produced. Spectrophotometry results made a standard curve that shows the relationship between the standard solution of IAA ( $\mathrm{x}$ ) and absorbance (y) will get a regression equation $\mathrm{y}$ 
$=0.0029 \mathrm{x}-0.0015$ to calculate IAA concentration of bacteria isolates. The concentration of IAA-produced by bacteria isolate was calculated by change variables $y$ with the absorbance. IAA standard curve results will be obtained by the value $x$ that has meant the concentration of IAA. The IAA concentration value was measured in ppm.

The IAA production by IAA-producing bacteria isolates

There are forty isolates bacteria from the previous study that can produce the IAA hormone (Prabaningtyas et al. 2017). The determination of the IAA concentration was calculated by linear regression from the standard curve to show the concentration of the sample solution from the measurement results. As a result, ten isolates that have the highest ability to producing IAA can be seen in (Figure 1). Based on the average product, forty bacterial isolates showed that the optimum time to produce IAA hormone was at $48 \mathrm{~h}$ incubation (in Supplementary File 2). The average of IAA produced by the ten highest bacterial isolates incubated at various times was showed in Figure 1. From figure 1, the isolate with code "12" has the most increased average IAA hormone production.

Indole Acetic Acid (IAA) is a member of the group of phytohormones generally considered to be the most crucial auxin. IAA production is characterized by a pink discoloration on TSB media when Salkowski reagent is dropped. The IAA calculation is due to the interaction between IAA and $\mathrm{Fe}$ that forms complex compounds $\left[\mathrm{Fe}_{2}(\mathrm{OH})_{2}(\mathrm{IA})_{4}\right]$. The factor that influences the reaction between Salkowski reagents and IAA is light. The darker the IAA-production will not be disrupted because dark conditions can avoid the degradation of IAA produced due to high light intensity (Sukmadi 2013).

IAA-production with variation incubation times ranging from 0 to $24 \mathrm{~h}$ has increased. In incubation $48 \mathrm{~h}$, entered the peak of IAA production, which was high, but in incubation $72 \mathrm{~h}$, IAA production had decreased. Besides, incubation times more than $72 \mathrm{~h}$ have also resulted in low IAA-production (Meza et al. 2014). Auxin production by all isolates increased when culture media supplemented with tryptophan as a precursor for synthesis IAA (Zhao 2010). IAA was not produced or produced in negligible quantity in the L-tryptophan free media. Some microorganisms produce auxins in the presence of a suitable precursor such as L-tryptophan (Mohite 2013).

The various types of isolate are documented for the production of IAA, exploit different IAA biosynthesis pathways, and single bacterial strain sometimesencompassing more than one pathway. The earlier data, the production of IAA can vary among other species and other strains. It is also influenced by culture condition, growth stage, and substrate availability (Khan et al. 2016).

The results of the analysis showed that the isolate of bacteria with the code "12" was able to produce the highest IAA hormone with an average of $30.23 \mathrm{ppm}$. The isolate " 12 " producing IAA is optimal at $48 \mathrm{~h}$ incubation because the bacteria enter the stationary phase. This phase is influenced by the enzyme content used in the biosynthesis of tryptophan to produce IAA, also in line with growth (Kresnawaty et al. 2008). The isolate code "12" included in the high category in producing IAA hormones when compared with bacterial isolates originating from soil or other roots. This difference is due to the ability of each bacterial isolate produced is different, the condition of each sampling location, incubation time, and standard solutions used (Susilowati et al. 2018; Pattern and Glick 2002; Khairani 2009). IAA hormone production through biosynthetic pathways with intermediate tryptophan as a precursor bacteria (Spaepen and Vanderleyden 2011). The indole-3-pyruvate (IpyA) pathway can be carried out by plants and bacteria, while the indole-3-acetamide (IAM) pathway can only be used by bacteria (Spaepen et al. 2007).

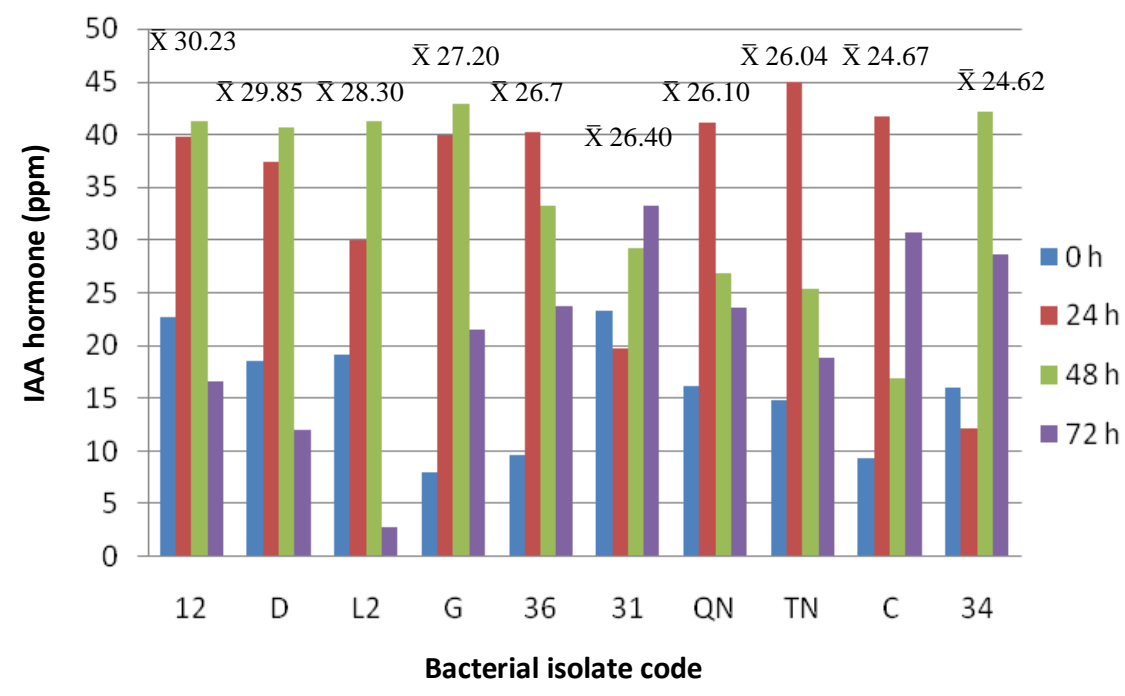

Figure 1. Ten bacterial isolates that produce the highest IAA hormone 


\section{OD measurement}

The growth curve based on OD for ten isolates that has the highest ability in producing IAA can be seen in (Figure 3 ). Generally, the growth of those isolates increasing from $0 \mathrm{~h}$ to $72 \mathrm{~h}$ incubation, but the complete phases cannot be defined. This data also shows the correlation to IAA production, where OD explains bacterial growth in line with IAA production. Hence, the growth curve of isolates probably contributes to the concentration of IAA that has produced.

Optical density (OD) measurement results on "12" code bacterial isolates showed that at incubation $72 \mathrm{~h}$ had the highest OD value. It is probably proved that the $72 \mathrm{~h}$ incubation was the end of the stationary phase. The OD measurement in (Figure 2) shows that the higher incubation resulting in a high OD value but inversely proportional to the IAA concentration that was produced because the bacteria can grow and divide continuously when nutrients in the media are still available. The higher OD value indicating the amount of microorganisms that grow in media culture was high (Benson 2001).

The interaction of OD and IAA production was measured at the same incubation time. The OD measurement results are used to determine whether the bacterial growth phase is the same as the resulting IAA production. Based on the results of research related to the interaction between OD and IAA hormone production when viewed from the incubation time, it has the same thing that from the 0 to $24 \mathrm{~h}$ incubation time has increased the number of IAA. In contrast, at the $48 \mathrm{~h}$ and $72 \mathrm{~h}$ incubation time, there is an increase or decrease in IAA hormones concentration... Hence, each isolate has different abilities to decompose, and convert the tryptophan contained in the media. The early incubation of the available nutrients is still high, so that the resulting IAA production is also high (Mike-Anosike et al. 2018).

The location of sampling taken into account, namely the environmental conditions in different lake regions such as temperature, $\mathrm{pH}$, the intensity of light, and nutrition, had an essential influence on bacteria in their metabolic activities (Sinaga et al. 2016). TSB media influences the TSB contained tryptophan amino acid in the form of peptone, functions as a micronutrient in a media, and contains glucose as an energy source in bacterial growth. The results of the highest IAA hormone concentration will be characterized by the colony and cell morphology to show the bacterial group.

\section{Bacterial identification}

Morphological characterization of the colony and cell morphology with the highest bacteria ability to produce IAA was a bacterial isolate code " 12 ". Based on the morphological characterization of colonies and cells, the bacteria is included in the Enterobacteriaceae group (Bergey 2009). The Gram observation of bacterial isolate 12 was available in (Figure 3 ).

The morphology characteristics of isolate code " 12 " are white colony color, shape of circular, colony edge of heave, the elevation of convex, the density of dense, gloomy, diameter $1,4 \mathrm{~mm}$, the growth pattern like a sword in NA media, negative gram type, basil, transparent cell color, size of length $\pm 3 \mu \mathrm{m}$ and diameter $\pm 1 \mu \mathrm{m}$, present of capsule and spore, shape spore-like oval, location spore central, and anaerobic facultative.

Based on morphological, the bacterial isolate " 12 " characterization include in Enterobacteriaceae, correlate to phylogenetic tree construction with the Neighbor-Joining method, showed that bacterial isolate " 12 " identified as Enterobacteriaceae with bootstrap value reaching 92 (Figure 4). Based on this phylogenetic tree, the reliable species cannot be defined trust; moreover, the genetic distance analysis informed that isolate closely related with a member of Enterobacter asburiae strain JCM6051 with similarity $94.12 \%$ (Table 1). The threshold for definition level in species generally accepted with value 0.03 (Johnson et al. 2019); based on that threshold, species cannot be defined truly.

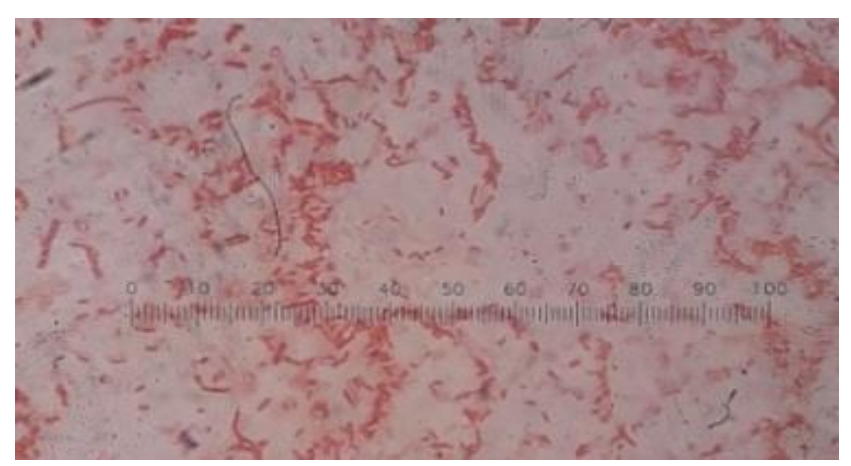

Figure 3. Gram-staining of isolate " 12 ” (1000x magnification)

Figure 2. Growth curve of 10 bacterial isolates that produced the highest IAA hormone. 


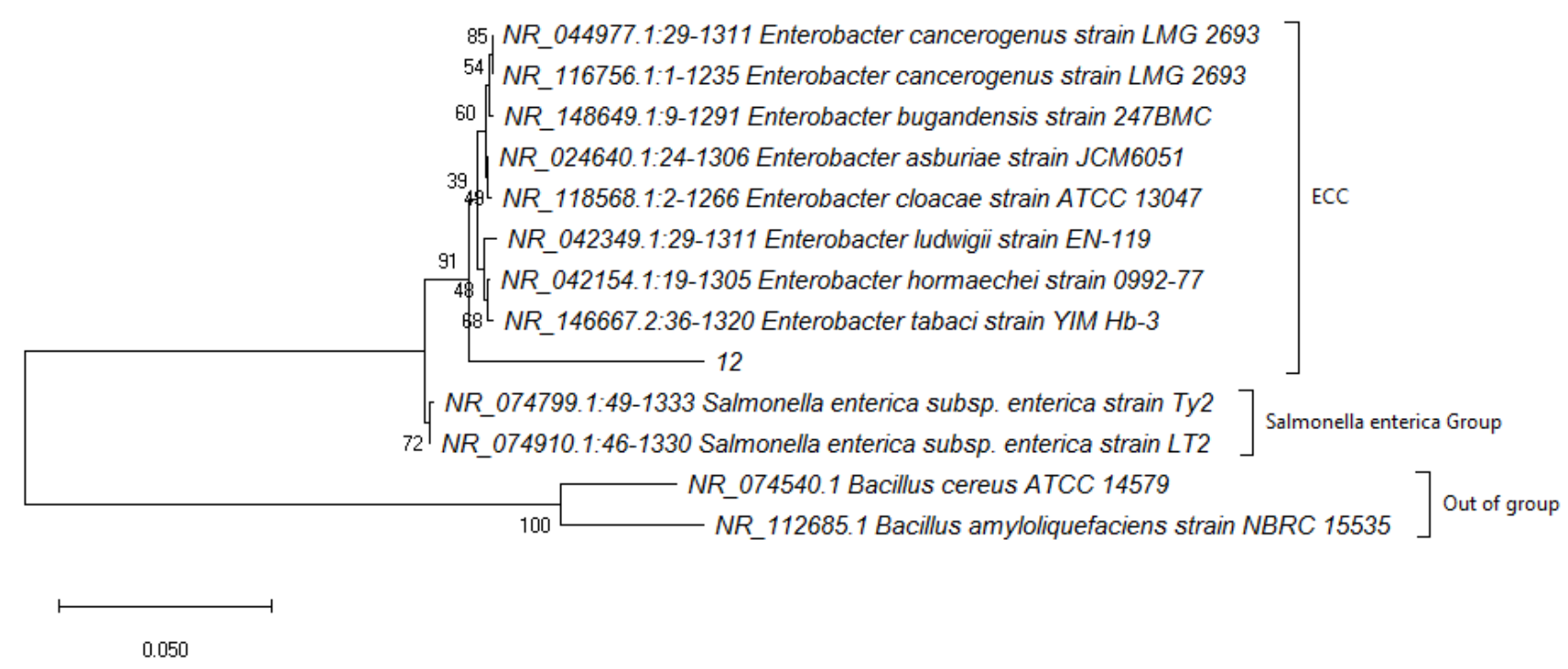

Figure 4. Neighbor-Joining tree with 1000 replicates. Species in the genus Salmonella and Bacillus were used as out of the group.

Table 1. The similarity $16 \mathrm{~S}$ rRNA sequence from sample 12 with reference sequences from blast nucleotide

\begin{tabular}{|c|c|c|c|}
\hline Sequence & Group & Similarity $(\%)$ & $\begin{array}{c}\text { Inner group } \\
\text { similarity (\%) }\end{array}$ \\
\hline NR_024640.1:24-1306 Enterobacter asburiae strain JCM6051 & ECC & 94.12 & 98 (include \\
\hline NR_042154.1:19-1305 Enterobacter hormaechei strain 0992-77 & ECC & 93.77 & sample 12) \\
\hline NR_042349.1:29-1311 Enterobacter ludwigii strain EN-119 & ECC & 93.41 & \\
\hline NR_044977.1:29-1311 Enterobacter cancerogenus strain LMG 2693 & ECC & 94.04 & \\
\hline NR_116756.1:1-1235 Enterobacter cancerogenus strain LMG 2693 & ECC & 94.04 & \\
\hline NR_118568.1:2-1266 Enterobacter cloacae strain ATCC 13047 & ECC & 94.12 & \\
\hline NR_146667.2:36-1320 Enterobacter tabaci strain YIM Hb-3 & ECC & 93.59 & \\
\hline NR_148649.1:9-1291 Enterobacter bugandensis strain 247BMC & ECC & 93.95 & \\
\hline NR_074799.1:49-1333 Salmonella enterica subsp. enterica strain Тy2 & Salmonella Group & 92.51 & 100 \\
\hline NR_074910.1:46-1330 Salmonella enterica subsp. Enterica strain LT2 & Salmonella Group & 92.51 & \\
\hline NR_074540.1 Bacillus cereus ATCC 14579 & Out of group & 69.26 & 94 \\
\hline NR_112685.1 Bacillus amyloliquefaciens strain NBRC 15535 & Out of group & 68.50 & \\
\hline
\end{tabular}

In our result, it is shown that the similarity $16 \mathrm{~S}$ rRNA within-group genus Enterobacter has a similarity value of around $98 \%$ (Table 1), indicating those sequences are homogenous. Sample can define in one species if it has a genetic distance of about $\geq 0.03$ or similarity about $\geq 97 \%$ from $16 \mathrm{~S}$ rRNA sequence comparison; if it below that value, the sample can conclude as novel species or different taxa (Bukin et al. 2019). All species member Enterobacter that has high similarity from blast program is known as ECC (Vogt et al. 2019), the graphic view of multiple alignment sequences in this study already in Supplementary material 3. ECC consists of several species such as E. asburiae, E. cloacae, E. hormachei, E. ludwigii, E. cancerogenus, E. bugandensis, E. tabaci E. mori, E. kobei, E. nimipressuralis, and E. xiangfangensis (Sophia et al. 2019).

These complex species have a high similarity of $16 \mathrm{~S}$ rRNA sequences, which are related to similar morphology; consequently, the identification in level species more difficult (Bickford et al. 2007). Based on that explanation, we conclude that our bacterial isolate code " 12 " could be defined as a novel-species in ECC.

Most species members of the ECC can dissolve phosphate, produce the IAA hormone, produce ammonia (Larasati et al. 2018; Nhu and Diep 2017), and produce the enzyme L-asparaginase (Prihanto et al. 2019). ECC can produce the IAA hormone through the indole-3-pyruvate (IPA) biosynthesis pathway (Schutz et al. 2003), and had high amounts of IAA from tryptophan was $0.90 \mathrm{~mL}$ (Koga et al. 1991).

Morphological characterization is related to genetic identification in bacteria. Morphological characterization is used only to describe the characteristics of bacterial isolates both macroscopic and microscopic to determine the species and group bacteria in their taxon level; it is necessary to identify genetically, one of which is using the full-length of $16 \mathrm{~S}$ rRNA gene. This gene could accurate in the classification of organisms at very high taxonomic resolution (Johnson et al. 2019). 
ECC has an essential role in the consortium between algae and bacteria to produce biomass utilizing the carbohydrates from complex biofilm biomass, and produced hydrogen close to the value obtained by a thermophilic anaerobic microbial consortium from pretreated algae biomass (Miranda et al. 2017). IAAproducing bacteria has been significantly shown to promote cell enlargement, affected oil accumulation, fatty acid composition, gene expression in $C$. vulgaris, and cell division in C. pyrenoidosa (Jusoh et al. 2015). Cell dry weight for the $C$. vulgaris showed $0.75 \mu \mathrm{M}$ and cell weight for the Scenedesmus sp. exhibit a maximum at $250 \mu \mathrm{M}$ (Bagwell et al. 2014). On a cell basis, chlorophyll and dry weight were inversely correlated against IAA concentration for the. $C$ vulgaris; these cell features were proportional in Scenedesmus sp.

In conclusion,. Bacteria isolate code "12" from Ranu Grati produces the highest IAA hormone concentration, with an average of $30.23 \mathrm{ppm}$. The morphological description of that bacterial isolate, identified as Enterobacteriaceae; also based on genotypical characterization with $16 \mathrm{~S}$ rRNA sequence, that bacterial isolate could be identified as a novel-species in EEC.

\section{ACKNOWLEDGEMENTS}

This research was funded by PNBP University of Malang (UM), Indonesia in 2019 with a PUI CAMRY scheme with No. Research 20.3.252/UN32.14.1/LT/2019.

\section{REFERENCES}

Aryantha INP, Lestari DP. 2004. The potency of IAA producing bacteria isolates on promotion the growth of mungbean sprout in hydroponic conditions. Jurnal Mikrobiologi Indonesia 9 (2): 43-46. [Indonesian]

Amini S, Susilowati R. 2010. Produksi biodiesel dari mikroalga Botryococcus brauni. Jurnal Squalen 5 (1): 23-32. [Indonesian]

Benson. 2001. Microbiological Application. McGraw Hill Publisher, New York.

Bickford D, Lohman DJ, Sodhi NS, Ng PK, Meier R, Winker K, Das I. 2007. Cryptic species as a window on diversity and conservation. Trends Ecol Evol 22 (3): 148-155.

Bergey DH, Boone DR. 2009. Bergey's Manual of Systematic Bacteriology, Vol. 3, 2nd ed. Springer Science-Business Media, New York.

Bagwell CE, Piskorska M, Soule T, Petelos A, Yeager CM. 2014. A Diverse Assemblage of Indole-3-Acetic Acid Producing Bacteria associate with unicellular green algae. Appl Biochem Biotechnol 173 (8): 1977-1984.

Bukin YS, Galachyants YP, Morozov IV, Bukin SV, Zakharenko AS, Zemskaya TI. 2019. The effect of $16 \mathrm{~S}$ rRNA region choice on bacterial community metabarcoding results. Sci Data 6: 190007. DOI: 10.1038/sdata.2019.7.

Carroll A, Somerville C. 2009. Cellulosic Biofuels. Ann Rev Plant Biol 60: $165-182$

Cappuccino JG, Sherman N. 2014. Microbiology, A Laboratory Manual. 10th ed. Pearson Education, Inc., United States of America.

de-Bashan LE, Antoun H, Bashan Y. 2016. Involvement of Indole-3Acetic-Acid produced by the growth-promoting bacterium Azospirillum spp. in promoting growth of Chlorella vulgaris. J Phycol 44 (4): 938-947.

Gordon SA, Weber RP. 1951. Colorimetric estimation of indoleacetic acid. Plant Physiol 26 (1): 192.

Gravel V, Antoun H, Tweddell RJ. 2007. Growth stimulation and fruit yield improvement of greenhouse tomato plants by inoculation with
Pseudomonas putida or Trichoderma atroviride: Possible role of Indole Acetic Acid (IAA). Soil Biol Biochem 39 (8): 1968-1977. DOI: 10.1016/j.soilbio.2007.02.015.

Jegathese SJP, Farid M. 2014. Microalgae as a renewable source of energy: A niche opportunity. J Renew Energ 2014. DOI: $10.1155 / 2014 / 430203$.

Jusoh M, Loh SH, Chuah TS, Aziz A, San Cha T. 2015. Indole-3-Acetic Acid (IAA) induced changes in oil content, fatty acid profiles and expression of four fatty acid biosynthetic genes in Chlorella vulgaris at early stationary growth phase. Phytochemistry 111: 65-71. DOI: 10/1016/j.phytochem.2014.12.022.

Johnson JS, Spakowicz DJ, Hong BY, Petersen LM, Demkowicz P, Chen L, Leopold SR, Hanson BM, Agresta HO, Gerstein M, Sodergren E, Weinstock GM. 2019. Evaluation of 16S rRNA gene sequencing for species and strain-level microbiome analysis. Nat Commun 10 (1): 111. DOI: 10.1038/s41467-019-13036-1.

Koga J, Adachi T, Hidaka H. 1991. IAA biosynthetic pathway from tryptophan via indole-3-pyruvic acid in Enterobacter cloacae. Agric Biol Chem 55: 701-706.

Kresnawaty I, Andanawarih S. 2008. Optimisasi dan pemurnian IAA yang dihasilkan Rhizobium sp. dalam medium serum lateks dengan suplementasi triptofan dari pupuk kandang. Menara Perkebunan 76 (2): 74-82. [Indonesian]

Khairani G. 2009. Isolasi dan uji kemampuan bakteri endofit penghasil hormon IAA (Indole Acetic Acid) dari akar tanaman jagung (Zea mays L.). [Hon. Thesis]. Departemen Biologi, Fakultas Matematika dan Ilmu Pengetahuan Alam, Universitas Sumatera Utara, Medan. [Indonesian]

Kawaroe M. 2015. Bioenergi dari Alga Laut. IPB Press, Bogor. [Indonesian]

Khan AL, Halo BA, Elyassi A, Ali S, Al-Hosni K, Hussain J, Al-Harrasi A, Jung L. 2016. Indole acetic acid and ACC deamination from endophytic bacteria improve the growth of Solanum lycopersicum. Electron J Biotechnol 58-64. DOI: 10.1016/j.ejbt.2016.02.001

Li Y, Horsman M, Wu N, Lan CQ, Dubois-Calero N. 2008. Biofuels from Microalgae. Biotechnol Prog 24 (4): 815-820. DOI: 10.1021/bp070371.

Lwin KM, Myint MM, Tar T, Aung WZM. 2012. Isolation of plant hormone (indole-3-acetic acid-IAA) producing rhizobacteria and study on their effects on maize seedling. Eng J 16 (5): 137-144.

Lestariani N. 2014. Analisis status trofik Ranu Grati, Pasuruan dan pengembangannya sebagai modul perkuliahan limnologi. [Disertation]. Program Pascasarjana, Universitas Negeri Malang, Malang. [Indonesian]

Larasati ED, Rukmi MI, Kusdiyantini E, Ginting RCB. 2018. Isolasi dan identifikasi bakteri pelarut fosfat dari tanah gambut. Bioma: Berkala Ilmiah Biologi 20 (1): 1-8. [Indonesian]

Mohite B. 2013. Isolation and characterization of Indole Acetic Acid (IAA) producing bacteria from rhizospheric soil and its effect on plant growth. J Soil Sci Plant Nutr. DOI: 10.4067/S071895162013005000051.

Meza B, de-Bashan LE, Bashan Y. 2015. Involvement of Indole-3-Acetic Acid produced by Azospirillum brasilense in accumulating intracellular ammonium in Chlorella vulgaris. Res Microbiol 166 (2): 72-83.

Miranda AF, Ramkumar N, Andriotis C, Höltkemeier T, Yasmin A, Rochfort S, Lal B. 2017. Applications of microalgal biofilms for wastewater treatment and bioenergy production. Biotechnol Biofuels 10 (1): 120

Mike-Anosike EE, Braide W, Adeleye SA. 2018. Studies on indole acetic acid (IAA) production by rhizobacteria and growth-promoting potentials. Intl J Adv Res Biol Sci 5 (2): 133-140.

Nghia NK, Tien TTM, Oanh NTK, Nuong NHK. 2017. Isolation and characterization of indole acetic acid-producing halophilic bacteria from salt affected soil of Rice-Shrimp farming system in the Mekong Delta, Vietnam. For Fish 6 (3): 69-77.

Nhu VTP, Diep CN. 2017. Isolation and characterization of endophytic bacteria in soybean (Glycine max L. (Merrill) cultivated on alluvial soil of Can Tho city, Vietnam. Intl J Innov Eng Technol 8 (3): 208221. DOI: $10.21172 /$ ijiet.83.028.

Pattern CL, Glick BR. 2002. Role of Pseudomonas putida Indole Acetic Acid in development of the plant root system. Appl Environ Microbiol Res 160: 127-133.

Palacios OA, Lopez BR, Bashan Y, de-Bashan LE. 2019. Early changes in nutritional conditions affect formation of synthetic mutualism between Chlorella sorokiniana and the bacterium Azospirillum 
brasilense. Microbial Ecol 77 (4): 980-992. DOI: 10.1007/s00248018-1282-1.

Pardi F, Gascuel O. 2016. Distance-based methods in phylogenetics. In Kliman RM (ed.). Encyclopedia of Evolutionary Biology. Elsevier, Nederlands.

Prabaningtyas S, Witjoro A, Suarsini E, Aridowi D, Nafizatuzamrudah ANA, Purnomo A, Permana YI. 2018. Vertical distribution of bacteria in various lakes of East Java, Indonesia. J Physics Conf Ser (1): 012017. DOI: :10.1088/1742-6596/1093/1/012017.

Prabaningtyas S, Witjoro A, Aridowi D, Aribah D, Basithoh YK. 2017 Co-culture mikroalga Chlorella sp. dan bakteri (penghasil IAA dan pelarut fosfat), prospek industri mikroalga masa depan. [Laporan Penelitian]. Jurusan Biologi, Fakultas Matematika dan Ilmu Pengetahuan Alam, Universitas Negeri Malang, Malang. [Indonesian]

Prihanto AA, Ardiansyah RF, Pradarameswari KA. 2019. Identifikas molekuler bakteri endofit penghasil L-asparaginase yang diisolasi dari mangrove buta-buta (Excoecaria agallocha). Jurnal Pascapanen dan Bioteknologi Kelautan dan Perikanan 14 (1): 29-34. [Indonesian]

Saitou N, Nei M. 1987. The neighbor-joining method: a new method for reconstructing phylogenetic trees. Mol Biol Evol 4 (4): 406-425.

Schutz A, Golbik R, Tittmann K, Svergun DI, Koch MH, Hubner G, Konig S. 2003. Studies on structure-function relationships of indole pyruvate decarboxylase from Enterobacter cloacae, an enzyme involved in the biosynthesis of the plant hormone Indole-3-Acetic Acid. Eur J Biochem 270 (10): 2322-2331. DOI: 10.1046/j.14321033.2003.03602.x.

Spaepen S, Vanderleyden J, Remans R. 2007. Indole-3-acetic acid in microbial and microorganism-plant signaling. J FEMS Microbiol Rev 31 (4): 425-448. DOI: 10.1111/j.1574-6976.2007.00072.x.

Spaepen S, Vanderleyden J. 2011. Auxin and plant-microbe interactions. Cold Spring Harbor Perspect Biol 3 (4): a001438.

Sharfina S. 2013. Struktur Komunitas Fitoplankton di Perairan Ranu Pani Kecamatan Senduro, Kabupaten Lumajang. [Hon. Thesis]. Jurusan Biologi Fakultas MIPA UM, Malang. [Indonesian]

Sukmadi RB. 2013. Aktivitas Fitohormon Indole-3-Acetic Acid (IAA) dari bebarapa isolat bakteri rhizosfer dan endofit. J Sains dan Teknologi Indon 14 (3): 221-227. DOI: 10.29122/jsti.v14i3.930. [Indonesian]
Sinaga ELR, Muhtadi A, Bakti D. 2016. Profil suhu, oksigen terlarut, dan pH secara vertikal selama 24 jam di Danau Kelapa Gading Kabupaten Asahan Sumatera Utara. Omni-Akuatika 12 (2). DOI: 10.20884/1.oa.2016.12.2.107. [Indonesian]

Shaik I, Janakiram P, Sujatha L, Chandra S. 2016. Isolation and identification of IAA producing endosymbiotic bacteria from Gracillaria corticata (J. Agardh). Intl J Bioassays 5 (12): 5179. DOI: 10.21746/ijbio.2016.12.0012.

Sa'adah AF, Fauzi A, Juanda B. 2017. Peramalan Penyediaan dan Konsumsi Bahan Bakar Minyak Indonesia dengan Model Sistem Dinamik. Jurnal Ekonomi Dan Pembangunan Indonesia, 17(2), 118137 https://doi.org/10.21002/jepi.v17i2.661.

Susilowati DN, Riyanti EI, Setyowati M, Mulya K. 2018. Indole-3-acetic acid-producing bacteria and its application on the growth of rice. AIP Conf Proc 2002 (1): 020016. DOI: 10.1063/1.5050112. Sivaramakrishnan R, Incharoensakdi A. 2020. Plant hormone-induced enrichment of Chlorella sp. Omega-3 fatty Acids. Biotechnol Biofuels 13: 7. DOI: 10.1186/s13068-019-1647-9.

Sophia V, Kim L, Ariane G, Dinkelacker, Baris B, Ingo BA, Silke P, Jan L. 2019. Fourier-Transform Infrared (FTIR) Spectroscopy for typing of clinical Enterobacter cloacae complex isolates.

Front Microbiol 10: 2582. DOI: 10.3389/fmicb.2019.02582.

Tandon P, Jin Q, Huang L. 2017. A promising approach to enhance microalgae productivity by exogenous supply of vitamins. Microbial Cell Factories 16 (1): 1-13. DOI: 10.1186/s12934-017-0834-2.

Udayan A, Kathiresan S, Arumugam M. 2018. Kinetin and Gibberellic acid (GA3) act synergistically to produce high value polyunsaturated fatty acids in Nannochloropsis oceanica CASA CC201. Algal Res 32: 182-192.

Vogt S, Löffler K, Dinkelacker AG, Bader B, Autenrieth I, Peter SM, Liese J. 2019. Fourier-transform infrared (FTIR) spectroscopy for typing of clinical Enterobacter cloacae complex isolates. Front Microbiol 10: 2582. DOI: 10.3389/fmicb.2019.02582.

Widodo L, Ihsan IM, Santoso AD. 2018. Profitabilitas biodiesel dari biomasa mikroalga. Jurnal Teknologi Lingkungan 19 (1): 117-124. [Indonesian]

Zhao Y. 2010. Auxin biosynthesis and its role in plant development. Ann Rev Plant Biol 61: 49-64. 